\title{
Historical perspectives of The American Association for Thoracic Surgery: Keith Reemtsma (1925-2000)
}

\author{
Abe DeAnda, Jr, MD, and Leora B. Balsam, MD
}

Keith Reemtsma (Figure 1) was born on December 5, 1925, to the Reverend Henry and Pauline Reemtsma, preceded by his sister Carol (born in 1922). His father was a Presbyterian minister and missionary and in 1938 moved the family to Fort Defiance, Arizona, part of the Navajo Reservation in the still-young state. The family was well received by the Navajo Indians, and the surname Reemtsma was transliterated to the Navajo "Sun rays." At 3900 acres, Fort Defiance made up only a small part of the approximately 1.7 million acres of Navajo reservation, but until 2002, the largest building was the Indian Hospital in Fort Defiance (Figure 2). Perhaps indicating his future path, one of Keith's favorite activities was observing the local surgeon in the operating room, eschewing some of the more popular activities on the reservation. The 1-room schoolhouse in Fort Defiance went only through the eighth grade, so in 1939, he was enrolled in a Presbyterian boarding school in Mt Pleasant, Utah, attending tuition free. He was very popular, becoming the president of his dormitory his sophomore year. It was there that he met Ann Pierce, who he would subsequently marry while in medical school.

As a high school senior, with World War II in progress, Reemtsma applied and was selected as part of the United States Navy V-12 program, a program in which the federal government paid tuition to participating colleges and universities. The individuals selected were paid $\$ 50$ per month, were required to wear Navy uniforms, and were subjected to routine and rigorous physical training. He selected the University of Idaho-Southern Branch (later the Idaho State College in Pocatello) for his college education, finishing his premedical studies in 2 years in 1945.

Reemtsma subsequently attended the University of Pennsylvania School of Medicine, graduating in 1949. His performance in medical school was stellar, graduating Alpha Omega Alpha, being inducted into the Phi Chi Medical Fraternity, and participating in the Deaver Surgical Society and Pierson Anatomical Society. His mentor was the pediatric surgeon C. Everett Koop, who strongly

From the Department of Cardiothoracic Surgery, New York University-Langone Medical Center, New York, NY.

Received for publication July 1, 2014; accepted for publication July 5, 2014; available ahead of print Aug 14, 2014

Address for reprints: Abe DeAnda, Jr, MD, Department of Cardiothoracic Surgery,

New York University-Langone Medical Center, 530 First Ave, Suite 9V,

New York, NY 10016 (E-mail: abe.deanda@nyumc.org).

J Thorac Cardiovasc Surg 2015;150:762-4

$0022-5223 / \$ 36.00$

Copyright (c) 2015 by The American Association for Thoracic Surgery

http://dx.doi.org/10.1016/j.jtcvs.2014.07.009

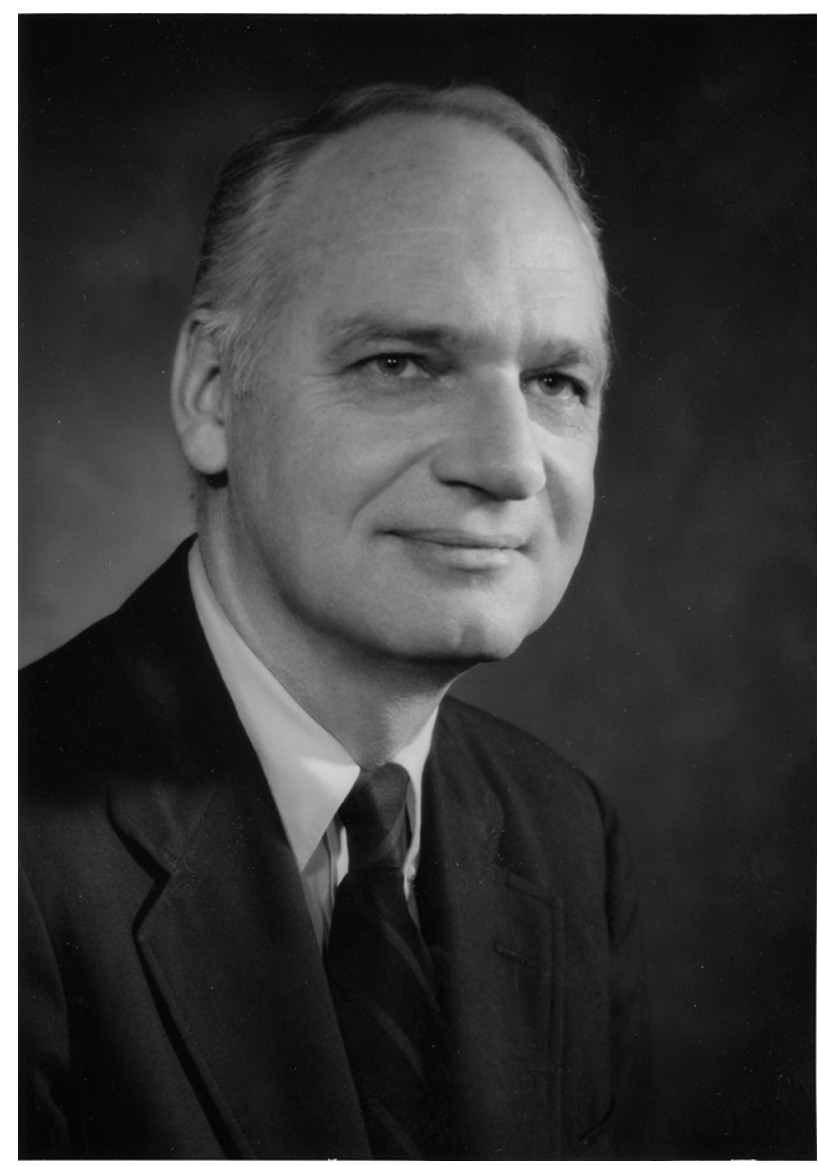

FIGURE 1. Keith Reemtsma, The American Association for Thoracic Surgery president 1990 to 1991.

encouraged his student to seek his postgraduate training in New York City. ${ }^{1}$ Thus, on finishing medical school, he headed to the East Coast to Columbia for his surgical residency, under the Chairmanship of George Humphreys, a pioneer in pediatric and thoracic surgery. During his residency, his first son, Lance, was born (1950).

Because he had attended college on a Navy-sponsored scholarship, it was not surprising that he was called to active duty during the Korean War after his internship. $\mathrm{He}$ served in the Marines with Frank Spencer (63rd American Association for Thoracic Surgery president ${ }^{2}$ ) as part of US Navy Surgical Team 16, Far East Command. As legend has it, Reemtsma, owing to his demeanor and body habitus and his service in Korea was the model for "Hawkeye Pierce" in Richard Hooker's novel MASH. This apocryphal story was frequently repeated by Reemtsma himself. 


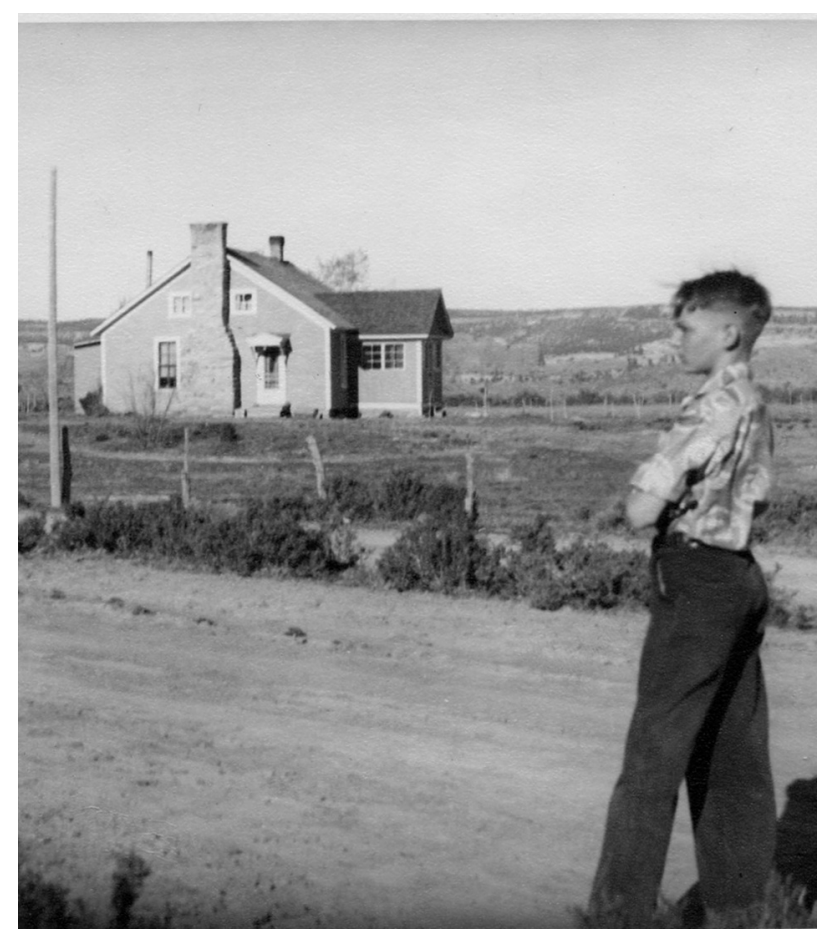

FIGURE 2. Reemtsma outside his home in Fort Defiance, Arizona.

In 1953, his son Dirk was born, and in January 1954, Reemtsma left Korea and returned to New York, finishing his residency at Columbia in 1957. He then headed south to Tulane University, where the Chairman of the surgical department, Dr Oscar Creech, Jr, had recruited Reemtsma to help build a cardiac surgery service. Because cardiac surgical referrals were low and Reemtsma was not one to sit around, he turned his attention toward renal transplantation. He began his work on xenotransplantation (referred to as "heterotransplantation"), studying the feasibility of cross-species chimpanzee-to-human kidney transplants. He was impelled to proceed down this path because the performance of cadaveric organs was poor and "We were reluctant to press the use of volunteer humans for ethical, scientific and legal reasons." 3 At the 1964 American Surgical Association meeting in Hot Springs, Virginia, Reemtsma presented Tulane's experience of 6 xenotransplants, with 1 patient surviving 9 months. His work met with mixed approval; however, the tenacity of his approach was appreciated, and he was promoted to full professor in 1966, further enhancing his visibility in the surgical world.

That same year, he was recruited and headed to the University of Utah, where he would serve as the Chairman of the Department of Surgery (from 1966 to 1971) and continue working on xenotransplantation. Reemtsma recruited the original inventor of kidney dialysis, Dr Willem Kolff. Kolff had played a role in the development of heart-lung machines and the first production of the artificial kidney and became the head of the University of Utah's Division of Artificial Organs and Institute for Biomedical Engineering. Both Reemtsma and Kolff were instrumental in assembling a cadre of surgeons and engineers that ultimately implanted the first artificial heart.

Nineteen seventy-one was a pivotal year, with Reemtsma moving back to New York City to become chairman of the Department of Surgery of the Columbia University College of Physicians and Surgeons, a position he would hold until 1994. Shortly thereafter, Dirk left for college and Keith and Ann were divorced. He remarried Judy Towers, a New York-based medical television producer in 1972 and remained married until his death.

Reemtsma made his mark at Columbia by invigorating research, in particular, in transplantation and cardiac surgery, by advocating for greater specialization in clinical activity and by strengthening the residency training program. In an era in which cardiac transplantation had largely been abandoned in the United States except for Shumway's program at Stanford and Lower's program in Virginia, Reemtsma was committed to bringing Columbia's program front and center into the controversial arena of heart transplantation. His efforts initially met with some reluctance from the administration, and Reemtsma's first cardiac transplant reportedly was booked as a triple valve replacement to avoid being noticed (personal communication, Frank Spencer, 2014). His program would be the first to use mechanical circulatory support in the form of an intra-aortic balloon pump as a bridge to transplantation. ${ }^{4}$ He used to startle some of his residents at the end of a successful operation by saying, modestly of course, "another 'goddam' miracle" (personal communication, Judy Reemtsma, 2013).

In May 1991, Dr Reemtsma delivered the presidential address at the 71st Annual Meeting of The American Association for Thoracic Surgery, in Washington, DC. His talk was titled "Discovery in Surgery: Reflections on a Golden Age." The talk was not meant to be a survey of a time past, but rather an acknowledgement and celebration of a current time with the forewarning that “...The people in this room, and our colleagues, especially the new members and the not-yet members of this Association, will define how long this golden age will last and which directions it will take." Four milestones were briefly discussed: Gibbons' (41st AATS president) development of the heart-lung machine; Voorhees' discovery of plastic-based vascular prostheses; Starr and Edwards' creation of the prosthetic valve; and Shumway (67th AATS president) and Lower's studies, which led to clinical heart transplantation. Reemtsma then briefly touched on his own work in xenotransplantation before turning his attention to the future. Some of his ideas demonstrated remarkable prescience: the development and clinical application of an artificial heart, 


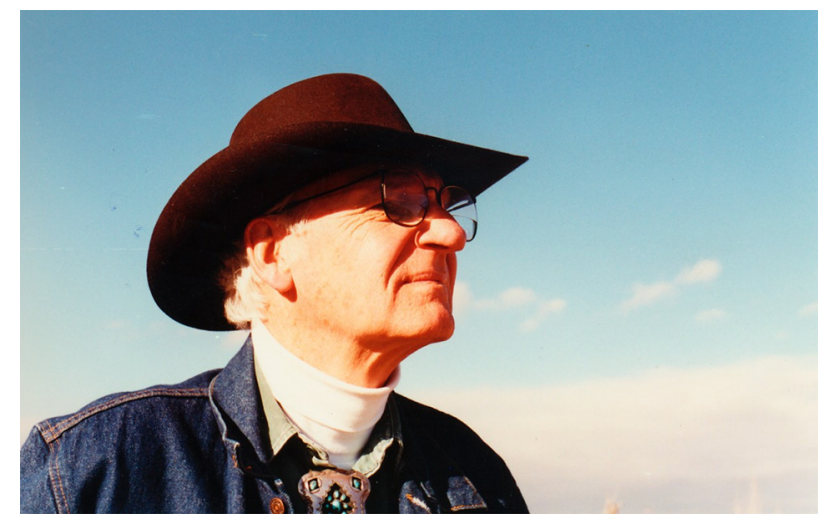

FIGURE 3. Keith Reemtsma.

"miniaturization" of procedures, and the application of molecular biologic approaches to "...provide specific tools to combat cancer and other diseases."

Reemtsma had begun his talk by comparing the contemporary cardiothoracic surgeon with early explorers on their own voyages of discovery. He noted that the comparison was not exact "...because our work involves manipulation as well as observation and exploration." He ended his talk by adding another aspect of our career that perhaps early explorers did not have to contemplate, "...we should be prepared to answer, as citizens and not only as surgeons, the demands of society that we justify our efforts on the basis of their value to us all."

His own interest in xenotransplantation continued, and at the inaugural meeting of the Xenotransplantation Society in October 1999, he described the theoretical advantage of transplanting “...non-human islet cells [which] might not be attacked by auto-immune processes." ${ }^{\circ 6}$ It probably gave him some satisfaction to have learned that, 1 month before his death, a team from Canada successfully performed such a transplant.

Reemstma had a variety of interests outside the operating room and hospital, some of which might have amazed his friends. In the last years of his life, perhaps as a tribute to his great grandfather's Dutch ancestry, he became interested in writing a play involving the artist Jan Vermeer and the scientist Anton van Leewenhoek, “...both born in Delft at the same time and both inventors of different ways of seeing" (personal communication, Judy Reemtsma, 2013).

Friends, family, and colleagues described Reemstma as an optimist and visionary; he would look beyond the ordinary and dream big (Figure 3). His clinical interests pushed the envelope of what others thought was possible, leading him to explore new and taboo frontiers such as transplantation and xenotransplantation. Coming from modest beginnings, he developed the imagination and curiosity that could make him a true pioneer. He was willing to take risks and accept uncertainty and was able to see opportunities where others did not. He was known for his sense of humor and confidence and took great pride in the legacy of trainees he left behind. He helped establish the Reemtsma Center for Innovation and Outcomes Research at Columbia and was honored at Columbia with the Keith Reemtsma Society for Cardiovascular Medicine and at the University of Pennsylvania with the Keith Reemtsma Surgical Resident of the Year Award. When receiving the Lifetime Achievement Award from the International Society of Heart and Lung Transplantation in 1999, Reemtsma quoted the inscription on St Paul's Cathedral in London, "If you seek my monument, look around you." Keith Reemtsma died on June 23, 2000, at age 74 of liver cancer.

The authors wish to thank Judy Reemtsma for her help in providing biographical materials, photographs, and anecdotes. We would also thank Dr Frank Spencer for his additional comments and reflections on the Korean War.

\section{References}

1. Herter FP, Jaretzki A III, eds. A Proud Heritage (An Informal History of Surgery at Columbia). New York: Columbia University Press; 2003:90.

2. DeAnda A, Galloway AC. Historical perspectives of The American Association for Thoracic Surgery: Frank Cole Spencer, MD. J Thorac Cardiovasc Surg. 2013;145:906-8.

3. Reemtsma K, McCracken BH, Schlegel JU, Pearl MA, Pearce CW, DeWitt CW, et al. Renal heterotransplantation in man. Ann Surg. 1964;160:384-410.

4. Bregman D, Drusin R, Edie RN, Dobelle WH, Hardy MA, Reemtsma K. Successful cardiac transplant after maintenance with intra-aortic balloon pump. Lancet. 1978;2:525.

5. Reemtsma K. Discovery in surgery: reflections on a golden age. J Thorac Cardiovasc Surg. 1991;102:653-6.

6. Reemtsma K. Address by the Honorary Founding President of the Xenotransplantation Society. The eye of an eagle: xenobiology and the quest for bioadvantage. Xenotransplantation. 2000;7:80-2. 